\title{
Association between IGF1/Tasl polymorphism and milk traits of Polish Holstein Friesian cows
}

\author{
Małgorzata Szewczuk', Sławomir Zych² and Ewa Czerniawska-Piątkowska'
}

'Laboratory of Molecular Cytogenetics, Department of Ruminant Science, The West Pomeranian University of Technology, Szczecin, Poland, '2Laboratory of Biochemistry, Serology and Genetic, Vet Diagnostic Laboratory "LaboWet" s.j., Szczecin, Poland

\begin{abstract}
The study was carried out on 658 Polish Holstein Friesian cows. A transversion of $A \rightarrow C$ in the P1 promoter region of bovine IGF1 gene at position 977 bp upstream from the start codon in exon 1 was identified using ACRS-PCR method. Reverse primer introduced an artificial Tasl restriction site. Three genotypes (AA, AC, CC) were found in the analysed herd of dairy cows occurred with a frequency of $0.766,0.213$ and 0.021 , respectively. In the presented study, the statistically significant differences between individuals of different /GF1/Tas genotypes were found in milk, fat and protein yield. In the 2nd and 3rd lactations, the cows carrying the CC genotype produced more milk than the AA individuals $(P \leq 0.05)$. In the case of protein and fat yield, similar tendencies were observed.
\end{abstract}

Keywords: IGF1, polymorphism, milk traits, Holstein Friesian

\section{Zusammenfassung}

\section{Zusammenhang zwischen dem IGF1/TasI Polymorphismus und der Milchleistung bei Polnischen Holstein Friesian Kühen}

Die Untersuchungen erfolgten an 658 Kühen einer Polnischen Holstein Friesian Herde. Mit Hilfe der ACRS-PCR-Methode wurde die Transversion A $\rightarrow$ C im Promotor P1 des IGF1-Gens in der Position 977 Basenpaare vor dem Startcodon im 1. Exon identifiziert. Die Startersequenz hat eine künstliche Schnittstelle für das Restriktionssystem Tasl eingeführt. Drei Genotypen wurden nachgewiesen: $\mathrm{AA}, \mathrm{AC}$ und $\mathrm{CC}$ mit den Frequenzen 0,766, 0,213 und 0,021. Es wurde ein signifikanter Zusammenhang zwischen den IGF1/TasI Genotypen und der Milchleistung sowie der Eiweiß- und Fettleistung festgestellt. In der 2. und 3. Laktation erzielten Kühe mit dem CC-Genotyp signifikant höhere Milchleistungen als Kühe des AA-Genotyps. Ähnliche Zusammenhänge wurden bei der Fett- und Eiweißleistung beobachtet.

Schlüsselwörter: IGF1, Polymorphismus, Milchleistung, Holstein Friesian 


\section{Introduction}

Most biological traits, such as milk, growth or reproductive traits, behavior and disease resistance, have a complex inheritance, which means that they are controlled by multiple genes and influenced by environmental factors. DNA polymorphisms are potentially useful as markers of quantitative trait loci (QTL). Studies have investigated polymorphisms within functional genes affecting milk production traits (milk yield, protein yield, fat yield, protein content and fat content) to determine whether the polymorphisms could be useful markers of QTL (Freyer et al. 2003). The somatotropic axis genes were often selected in these studies because of their biological significance on the quantitative traits of interest.

The growth hormone $(\mathrm{GH})$ is synthesized in the pituitary gland and released to circulation (Dybus \& Grzesiak 2006). GH has a mainly direct effect on the liver where is triggered a signal to synthesis and release of insulin like growth factor I (IGF-I) (Biereder et al. 1999, Kovacs et al. 2006). Although the increased expression of IGF-I in liver in response to GH is well characterized, the intracellular signaling pathways that mediate this effect have not been identified. One possibility is that GH-stimulated IGF-I expression is regulated by the JAKSTAT5b pathway (Davey et al. 2001).

The actions of IGF-I are modulated by a family of six high-affinity IGF binding proteins (IGFBP 1-6). In the target tissues non-bind IGF-I is known to interact with the insulinrelated receptors (IGF-IR, IGF-IIR or IR). The IGF-I type 1 receptor seems to be the proper »physiological« receptor (Baumrucker \& Erondu 2000, Nedbal et al. 2000, Sirotkin et al. 2000).

In human, many clinical and experimental evidences suggest that the insulin-like growth factor receptor type I is involved in breast cancer etiology. In vitro, IGF-I/IGF-IR regulates breast cancer proliferation and survival (Sachdev \& Yee 2001). In bovine mammary cell culture models, IGF-I is a potent mitogen involved in the regulation of epithelial cell proliferation and differentiation (Baumrucker \& Stemberger 1989). IGF-I is believed to mediate galactopoietic effects from exogenous bovine GH (Sharma et al. 1994). However, in the mammary gland IGF-I can act in a paracrine or endocrine manner (Plath-Gabler et al. 2001). Thus the potential role of IGF-I in bovine mammary gland development and the stimulation milk synthesis has been studied extensively at the molecular level.

Insulin-like growth factor I is a 70 amino-acid, single chain polypeptide encoded by a single gene (EMBL accession no. X15726; Fotsist et al. 1989). The IGF1 gene is highly conserved across mammalian species. Mature IGF-I is encoded only by parts of exons 3 and 4 . Transcripts derived from the exons 1 and 2 are alternately spliced onto exon 3 to generate two mRNA species (class 1 and class 2) and are regulated by distinct promoters (Adamo et al. 1991, Kim et al. 1991). There is extremely high conservation of both the nucleotide (93\%) and amino acid (96\%) sequences between bovine and human IGF-IA class. Mapped on chromosome 5 in cattle (Bishop et al. 1991), the IGF1 gene showed several polymorphisms as described previously (Zych et al. 2007).

The objectives of the present study were to estimate the allele and genotype frequencies of the IGF1/Tasl polymorphism and to determine associations between these polymorphisms and milk production traits. No other papers were found concerning effects of IGF1/Tasl polymorphism on milk production traits. 


\section{Material and methods}

Six hundred and fifty-eight Polish Holstein-Friesian cows kept at the same farm located in the Lubuskie province were used in this study. Cows included in the analysis were required to have 305-day lactation (all animals completed 1st, 2nd and 3rd successive lactations). The blood was collected from the external jugular vein into K3EDTA-containing test tubes. Genomic DNA was isolated from the peripheral blood using the MasterPure Genomic DNA Purification Kit (Epicentre Technologies).

A 146-bp PCR product was amplified using the Biometra thermal cycler. The PCR reaction mixture and conditions were the same as those described previously by Zych et al. (2007). The Amplification Created Restriction Sites - Polymerase Chain Reaction (ACRS-PCR) primers, designed by Zych et al. (2007), were applied:

\section{IgfP1F 5' TCA TCC AGC TGA GAG ATT TGA AT 3' \\ IgfP1R 5' TGT GTG TGT GTG TGT GTG TG스 AT 3'}

The genotypes were identified by restriction analysis. The PCR-amplified DNA was digested with 5 units of the Tasl restriction enzyme (10 U/ $\mu$ l, $\downarrow$ AATT; MBI Fermentas/ABO, Gdansk, Poland) at $65^{\circ} \mathrm{C}$ for $3 \mathrm{~h}$. The products was separated on $2 \%$ agarose gels (Prona Basic, le GQT) with ethidium bromide staining. The gels were visualized under UV light (312 nm) using the Vilber Lourmat transilluminator.

An association of the IGF1/TasI polymorphism with milk yield (in $\mathrm{kg}$ ), milk fat and protein yield (in kg), as well as milk fat and protein content (percentage) was analysed.

The analysis of milk performance was based on the data obtained from the official milk recordings. Statistical calculations were performed using a General Linear Model (GLM). The following statistical model was used:

$$
Y_{i j k l}=\mu+G_{i}+C S_{j}+s_{k}+\beta\left(x_{l}-A_{j}\right)+e_{i j k l}
$$

where $Y_{i j k l}$ is the analysed trait, $\mu$ is the overall mean, $G_{i}$ is the fixed effect of IGF1 genotype $(i=1, \ldots 3), C S_{j}$ is the fixed effect of calving season $(j=1,2), s_{k}$ is the random effect of sire $(k=1$, ...254), $\beta$ is the linear regression coefficient of calving age, $x_{l}$ is the calving age of a cow, $A_{1}$ is the mean calving age and $e_{i j k l}$ is the random error.

The significance of differences between particular traits for each lactation apart was tested using analysis of variance with Tukey's test (Statistica 9.0 PL software package).

\section{Results}

A transversion of $\mathrm{A}$ (allele $A$ ) to $C$ (allele $C$ ) in the P1 promoter region of IGF1 gene was identified using ACRS-PCR method. Primer IgfP1R introduced an artificial Tasl restriction site. Digestion of the $146 \mathrm{bp}$ PCR product with the above-mentioned restriction nuclease resulted in two DNA bands (122 and $24 \mathrm{bp}$ ) for homozygote AA and three bands (146, 122 and $24 \mathrm{bp}$ ) for the AC heterozygote. The DNA amplified from homozygous CC animals remained undigested with TasI restrictase. Allele and genotype frequencies for analysed polymorphism are shown in Table 1. The AA genotype occurred with a frequency of 0.766 , AC with 0.213 and CC with 0.021 . 
Table 1

The number and frequency of /GF1/Tasl genotypes and alleles of cows under study

\begin{tabular}{lcccccr}
\hline & \multicolumn{3}{c}{ IGF1/Tasl genotype } & Total & \multicolumn{2}{c}{ Allele } \\
& $\mathrm{AA}$ & $\mathrm{AC}$ & $\mathrm{CC}$ & & $\mathrm{A}$ & $\mathrm{C}$ \\
\hline $\mathrm{n}$ & 504 & 140 & 14 & 658 & 0.872 & 0.128 \\
frequency & 0.766 & 0.213 & 0.021 & 1.000 & & \\
\hline
\end{tabular}

Table 2 presents means $(\bar{x})$ and standard deviations (SD) for selected milk traits of cows under study in successive lactations.

Table 2

Means and standard deviations of milk performance traits in cows with different IGF1/TasI genotypes

\begin{tabular}{|c|c|c|c|c|c|c|c|}
\hline \multirow[t]{3}{*}{ Milk trait } & \multirow[t]{3}{*}{ Lactation } & \multicolumn{6}{|c|}{ IGF1/TasI genotype } \\
\hline & & \multicolumn{2}{|c|}{$\mathrm{AA}$} & \multicolumn{2}{|c|}{$A C$} & \multicolumn{2}{|c|}{ CC } \\
\hline & & $\bar{x}$ & SD & $\bar{x}$ & SD & $\bar{x}$ & SD \\
\hline Milk, kg & $1 s t$ & 6338 & 707.0 & 6269 & 694.1 & 6440 & 526.6 \\
\hline Fat, kg & & 263 & 39.3 & 261 & 43.9 & 262 & 21.1 \\
\hline Fat, $\%$ & & 4.14 & 0.33 & 4.15 & 0.42 & 4.07 & 0.21 \\
\hline Protein, kg & & 220 & 27.8 & 216 & 26.3 & 219 & 20.9 \\
\hline Protein, $\%$ & & 3.47 & 0.14 & 3.44 & 0.15 & 3.40 & 0.14 \\
\hline Milk, kg & 2nd & $6918^{\mathrm{a}}$ & 1108.6 & 7143 & 957.2 & $7433^{\mathrm{a}}$ & 421.4 \\
\hline Fat, kg & & $290^{A}$ & 48.9 & 297 & 46.5 & $312^{\mathrm{A}}$ & 32.7 \\
\hline Fat, $\%$ & & 4.20 & 0.27 & 4.15 & 0.24 & 4.20 & 0.29 \\
\hline Protein, kg & & $228^{\mathrm{a}}$ & 38.8 & 232 & 37.5 & $242^{\mathrm{a}}$ & 26.1 \\
\hline Protein, $\%$ & & $3.30^{\mathrm{A}}$ & 0.24 & $3.25^{\mathrm{A}}$ & 0.19 & 3.26 & 0.24 \\
\hline Milk, kg & $3 \mathrm{rd}$ & $7021^{\mathrm{a}}$ & 1197.2 & 7286 & 1003.1 & $7484^{\mathrm{a}}$ & 638.2 \\
\hline Fat, kg & & $316^{\mathrm{a}}$ & 56.7 & 322 & 52.3 & $332^{\mathrm{a}}$ & 42.0 \\
\hline Fat, $\%$ & & 4.50 & 0.31 & 4.42 & 0.32 & 4.44 & 0.39 \\
\hline Protein, kg & & $251^{\mathrm{A}}$ & 44.2 & 255 & 40.0 & $265^{A}$ & 33.1 \\
\hline Protein, \% & & 3.58 & 0.24 & 3.50 & 0.22 & 3.54 & 0.27 \\
\hline
\end{tabular}

Means within rows bearing the same letters differ significantly at: small letters $P \leq 0.05, \quad$ capitals $P \leq 0.01$.

In the present study, the statistically significant differences between individuals of different IGF1/Tas genotypes were found in milk, fat and protein yield. In the 2nd and 3rd 305-days lactations, the cows of the CC genotype produced more milk ( $+515 \mathrm{~kg} \mathrm{i}+463 \mathrm{~kg}$, respectively) than the AA individuals $(P \leq 0.05)$. In the case of protein and fat yield, similar tendencies were observed. The cows of the homozygous /GF1 CC genotypeyielded significantly more fat $(+22 \mathrm{~kg}$ and $+16 \mathrm{~kg}$ ) and protein (both $+14 \mathrm{~kg}$ ) than cows carrying the AA genotype (significations were different depending on successive lactation). Moreover, in the 2 nd lactation significant differences between $A A$ and $A C$ individuals in regard to protein concentration in milk were observed. No association was found between IGF1 RFLP-TasI and dairy production traits in the 1st lactation. 


\section{Discussion}

Polymorphisms in the promoter region, apart from missense mutations in the coding regions, are more likely to have a direct association with performance traits than intronic polymorphisms or silent mutations in the coding region. Candidate genes approach utilize genes that have well known biological functions related to the development or physiology of an important trait. In the study of Lien et al. (2000) the most convincing QTL peak was observed for a region in the middle part of chromosome 5 close to the insulin-like growth factor 1 (IGF1) gene. It is possible that IGF-I has different effects at different stages of growth, because expression of the IGFI gene is developmentally and physiologically regulated (Werner et al. 1994, Sirotkin et al. 2000). Additionally, nutritional stress significantly decreases the expression of the IGF1 gene and action of IGF-I at multiple steps (Underwood et al. 1994).

In the study of Plath-Gabler et al. (2001) the involvement of the IGFs system in mammary development and lactation of the cow, the temporal expressions of IGF-I and -II, its receptor type 1 (IGFR-1), IGF-binding proteins (IGFBPs) -1 to -6 and GH receptor (GHR) mRNA were examined. This was carried out for different stages of mammogenesis, lactogenesis, galactopoiesis and involution in the bovine mammary gland. The most of the IGF1 mRNA was expressed by adipocytes (about $80 \%$ of them showed a distinct IGF-I immunohistochemical staining). These results lead to conclude that paracrine/autocrine IGF-I is an important local factor for remodelling of the bovine mammary gland during involution and inactive during mammogenesis, lactogenesis and galactopoiesis. That may suggest an importance of endocrine IGF-I (produced by the liver) as primary mediator of galactopoietic effect of exogenous GH (Schams et al. 1991).

In most tissues IGF1 mRNA is only derived from exon 1 (P1 promoter), whereas both promoters (P1 and P2) are active in the liver (Shemer et al. 1992). Exon 2 has a classic signal peptide that should confer efficient secretion of mature peptide in contrast to the exon 1 derived long signal peptide, which may impede efficient IGF-I secretion. The function of class 2 IGF1 mRNA is to provide an efficient mechanism for rapid hepatic synthesis of IGF-I in response to GH (O'Sullivan et al. 2002).

The aim of this study was to search for possible associations between a SNP (single nucleotide polymorphism), the $A / C$ transversion at position $977 \mathrm{bp}$ upstream from the ATG codon in exon 1 (according to the GenBank sequence AF210383) in the $5^{\prime}$-noncoding region of the IGF1 gene (P1 promoter) and performance in milk production of Polish Holstein-Friesian cattle. The results indicated slightly effect of IGF1/TasI polymorphism on milk protein and fat yields, with preference of $C$ allele. However, the effects of these polymorphisms on beef or milk production traits were not yet investigated by the other scientists.

The dinucleotide $(\mathrm{CA})_{n}$ repeat polymorphism located $989 \mathrm{bp}$ to $954 \mathrm{bp}$ upstream from the ATG codon in the $5^{\prime}$ region of bovine IGF1 gene (Kirkpatrick 1992) is closely linked to regulatory elements of the IGF1 gene (Ge et al. 2001). In some microsatellites, the repeat units are interrupted by nonrepeat sequences, producing kind of a imperfect microsatellites. Occurrence of an AATA interrupt in the IGF1 microsatellite (P1 promoter) was investigated in a number of Artiodactyl species, namely pigs, camels, deer, cattle, goats, and sheep (Shariflou \& Moran 2000). IGF1/Tasl polymorphism is localized within "AATA« interrupt of $(C A)_{n}$ microsatellite, form two variants, $(C A)_{6} \operatorname{AATA}(C A)_{n}$ or $(C A)_{7} T A(C A)_{n}$ for $A$ and $C$ alleles, 
respectively. Conservation of this interrupt in an other number of Artiodactyl species remains further investigation. In fact, close proximity of the microsatellite to the transcription sites and the ability of the CA repeats to form a Z-DNA structure indicate an important functional role for this microsatellite as a potential enhancer element (Nordheim \& Rich 1983, Hamada et al. 1984).

Ge et al. (1997) detected and then reported (Ge et al. 2001) a significant effect of the IGF1/ SnaBI polymorphism, located 512 bp upstream from the ATG codon in the regulatory region of the IGF1 gene on growth traits in Angus cattle. Little is also known about the effect of the IGF1/SnaBI polymorphism on milk traits in cattle. However, in the several study, cows with the $A$ allele were always significantly associated with a higher milk, fat and protein yield (Siadkowska et al. 2006, Grzelak et al. 2007, Zych 2007, doctoral thesis). In contrast, no association was found between IGF1 RFLP-SnaBI and dairy production traits in Holstein cattle (Hines et al. 1998).

In conclusion, like the other polymorphisms, the utility of IGF1/Tasl polymorphism is strongly limited by low frequency of the rare $C$ allele. The effect of the mentioned locus is probably masked by loci with stronger positive or negative effects. Rather, the $A / C$ transversion may be only considered as a genetic marker, linked to other polymorphisms located closely in the same regulatory region of IGF1 gene. More tests are needed among random populations of calves to verify the associated effects of IGF1/Tasl polymorphism as the potential genetic marker.

\section{References}

Adamo ML, Ben-Hur H, LeRoith D, Berts Jr CT (1991) Transcription initiation in the two leader exons of the rat IGF1 gene occurs from dispersed versus localized sites. Biochem Biophys Res Commun 176, 887-893

Baumrucker CR, Stemberger BH (1989) Insulin and Insulin-Like Growth Factor-I stimulate DNA synthesis in bovine mammary tissue in vitro. J Anim Sci 67, 3503-3514

Baumrucker CR, Erondu NE (2000) Insulin-like growth factor (IGF) system in the bovine mammary gland and milk. J Mammary Gland Biol Neoplasia 5, 53-64

Biereder S, Wicke M, von Lengerken G, Schneider F, Kanitz W (1999) Growth of skeletal muscle and IGF-I in pigs of different sex. Arch Tierz 42, 619-628 [in German]

Bishop MD, Tavakkol A, Threadgill DW, Simmen FA, Simmen RCM, Davis ME, Womack JE (1991) Somatic cell mapping and restriction fragment length polymorphism analysis of bovine insulin-like growth factor $I$. J Anim Sci 69, 4306-4311

Davey HW, Xie T, McLachlan MJ, Wilkins RJ, Waxman DJ, Grattan DR (2001) STAT5b is required for GH induced liver Igf-I gene expression. Endocrinol 142, 3836-3841

Dybus A, Grzesiak W (2006) GHRH/Haelll gene polymorphism and its association with milk production traits in Polish Black and White cattle. Arch Tierz 49, 434-438

Fotsis T, Murphy C, Gannon F (1989) Nucleotide sequence of insulin-like growth factor I (IGF-I) and its IGF-IA precursor. Nucleic Acids Res 18, 676

Freyer G, Kühn C, Weikhard R (2003) Comparison of different statistical genetic approaches of QTL detection by evaluating results from a real dairy cattle data set. Arch Tierz 46, 413-423

Ge W, Davis ME, Hines HC (1997) Two SSCP alleles detected in the 5'-flanking region of bovine IGF-I gene. Anim Genet 28, 155-156

Ge W, Davis ME, Hines HC, Irvin KM, Simmen RCM (2001) Association of genetic marker with blood serum insulin-like growth factor-I concentration and growth traits in Angus cattle. J Anim Sci 79, 1757-1762 
Grzelak T, Kmieć M, Wojdak-Maksymiec K, Kulig H, Kowalewska-ŁuczakI (2007) IGF1/SnaBI gene polymorphism within Jersey cows. 2nd Polish Congress of Genetic, SGGW Warsaw, 18-20 September 2007 [in Polish]

Hamada H, Petrino MG, Kakunaga T, Seidman M, Stollar BD (1984) Characterization of genomic poly (dTdG) poly (dC-dA) sequences: structure, organization and conformation. Mol Cell Biol 4, 2610-2621

Hines HC, Ge W, Zhao Q, Davis ME (1998) Association of genetic markers in growth hormone and insulin-like growth factor I loci with lactation traits in Holsteins. Anim Genet 29 (suppl. 1), 63

Kim SW, Lajara R, Rotwein P (1991) Structure and function of a human insulin-like growth factor-I gene promoter. Mol Endocrinol 5, 1964-1972

Kirkpatrick BW (1992) Identification of a conserved microsatellite site in the porcine and bovine insulin-like growth factor-I gene $5^{\prime}$ flank. Anim Genet 23, 543-548

Kovăcs K, Völgyi-Csĭk J, Zsolnai A, Györkös I, Fĕsüs L (2006) Associations between the Alul polymorphism of growth hormone gene and production and reproduction traits in a Hungarian Holstein Friesian bull dam population. Arch Tierz 49, 236-249

Lien S, Karlsen A, Klemetsdal G, Vage DI, Olsaker I, Klungland H, Aasland M, Heringstad B, Ruane J, GomezRaya $L$ (2000) A primary screen of the bovine genome for quantitative trait loci affecting twinning rate. Mamm Genome 11, 877-882

Nedbal S, Zink N, Lahm H, Hoeflich A, Wolf E (2000) Functional dissection of the insulin-like growth factor (IGF) system-prospects for animal breeding. Arch Tierz 43, 223-230

Nordheim A, Rich A (1983) The sequence $(d C d A)_{n} \times(d T-d G)_{n}$ forms left-handed Z-DNA in negatively supercoiled plasmids. Proc Natl Acad Sci USA 80, 1821-1825

O'Sullivan DC, Szestak TA, Pell JM (2002) Regulation of hepatic insulin-like growth factor I leader exonusage in lambs: effect of immunization against growth hormone-releasing factor and subsequent growth hormone treatment. J Anim Sci 80, 1074-1082

Plath-Gabler A, Gabler C, Sinowatz F, Beriska B, Schams D (2001) The expression of the IGF family and GH receptor in the bovine mammary gland. J Endocrinol 168, 39-48

Sachdev D, Yee D (2001) The IGF system and breast cancer. Endocrine-Related Cancer 8, 197-209

Schams D, Graf F, Meyer J, Graule B, Mauthner M, Wollny C (1991) Changes of hormones, metabolites and milk after treatment with sometribove (recombinant methionyl bST) in Deutsches Fleck- and German Black and White cows. J Anim Sci 69, 1583-1592

Shariflou MR, Moran C (2000) Conservation within artiodactyls of an AATA interrupt in the IGF-I microsatellite for 19-35 million years. Mol Biol Evol 17, 665-669

Sharma BK, Vandehaar SJ, Ames NK (1994) Expression of insulin-like growth factor-l in cows at different stages of lactation and in late lactation cows treated with somatotropin. J Dairy Sci 77, 2232-2241

Shemer J, Adamo ML, Roberts Jr CT, LeRoith D (1992) Tissue-specific transcription start site usage in the leader exons of the rat insulin-like growth factor-I gene - evidence for differential regulation in the developing kidney. Endocrinol 131, 2793-2799

Siadkowska E, Zwierzchowski L, Oprządek J, Strzałkowska N, Bagnicka E, Krzyżewski J (2006) Effect of polymorphism in IGF1 gene on production traits in Polish Holstein-Friesian cattle. Anim Sci Pap Rep 24, 225-237

Sirotkin AV, Chrenek P, Makarevich AV, Huba J, Bulla J (2000) Interrelationship between breed, growth hormone genotype, plasma IGF-I level and meat performance in bulls of different ages. Arch Tierz 43, 591-596

Underwood LE, Thesen JP, Lemozy S, Ketelslegers JM, Clemmons DR (1994) Hormonal and nutritional regulation of IGF-I and its binding proteins. Horm Res 42, 145-151

Werner H, Adamo M, Roberts Jr CT, LeRoith D (1994) Molecular and cellular aspects of insulin-like growth factor action. Vitam Horm 48, 1-58

Zych S, Szewczuk M, Czerniawska-Piątkowska E, Szatkowska I (2007) A new ACRS-SNP in the 5' flanking region of the bovine insulin-like growth factor 1 (IGF1) gene (Brief report). Arch Tierz 50, 531-532 
Zych S (2007) Expression and polymorphism of selected genes encoding somatotropic axis in connection with milk production traits of Black- and White cows with different share of HF genes. Doctoral thesis, The West Pomeranian University of Technology, Szczecin, Poland

Received 7 January 2010, accepted 29 November 2010.

Corresponding author:

Małgorzata Szewczuk

email: malgorzata.szewczuk@zut.edu.pl

Laboratory of Molecular Cytogenetics, Department of Ruminant Science, The West Pomeranian University of Technology, Judyma 10, 71-460 Szczecin, Poland 